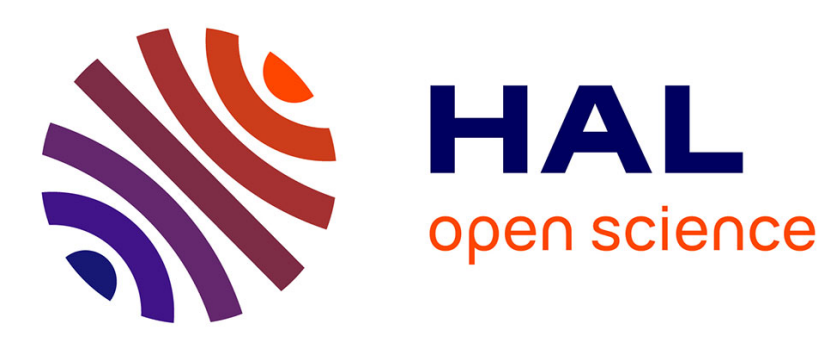

\title{
Are the New Trading Blocs Building or Stumbling Blocks? A Gravity Model Using Panel Data
}

\author{
Jérôme Trotignon
}

\section{To cite this version:}

Jérôme Trotignon. Are the New Trading Blocs Building or Stumbling Blocks? A Gravity Model Using Panel Data. 2009. halshs-00456590

\section{HAL Id: halshs-00456590 \\ https://shs.hal.science/halshs-00456590}

Submitted on 15 Feb 2010

HAL is a multi-disciplinary open access archive for the deposit and dissemination of scientific research documents, whether they are published or not. The documents may come from teaching and research institutions in France or abroad, or from public or private research centers.
L'archive ouverte pluridisciplinaire HAL, est destinée au dépôt et à la diffusion de documents scientifiques de niveau recherche, publiés ou non, émanant des établissements d'enseignement et de recherche français ou étrangers, des laboratoires publics ou privés. 


\section{Are the New Trading Blocs Building or Stumbling Blocks? A Gravity Model Using Panel Data}

Jérôme Trotignon

Décembre 2009

GATE Groupe d'Analyse et de Théorie Économique UMR 5824 du CNRS

93 chemin des Mouilles - 69130 Écully - France

B.P. $167-69131$ Écully Cedex

Tél. +33 (0)4 72866060 - Fax +33 (0)4 72866090

Messagerie électronique gate@gate.cnrs.fr

Serveur Web : www.gate.cnrs.fr 


\title{
Are the New Trading Blocs Building or Stumbling Blocks? \\ - A Gravity Model Using Panel Data -
}

\author{
Jérôme Trotignon \\ trotignon@gate.cnrs.fr \\ CNRS GATE Lyon St Etienne UMR 5824 \\ University of Lyon, France \\ 93, Chemin des Mouilles - B.P. 16769131 Ecully cedex France \\ Phone: 0472866110 Fax: 0472866090
}

\begin{abstract}
We will be asking ourselves if the trading blocs created or renewed since the end of the 1980s favor the multilateralization of trade, and so constitute building or stumbling blocks. In a gravity model using panel data, we estimate a set of three regional dummies representative of intra-bloc trade, extra-bloc exports and extra-bloc imports. Taking the resulting three coefficients as a starting point, we propose an original typology of trade creations / diversions and of trading blocs. In applying it to our results, all the groups chosen as well as the Economic and Monetary Union, are shown to be building blocks. No trade diversion is noted, with the exception of an export diversion brought about by North American Free Trade Agreement.
\end{abstract}

Key-words: trade integration, gravity model, trade creation / diversion, building / stumbling blocks

JEL: F13, F15, C23 


\section{Introduction}

The debate on the relationship between regionalism and multilateralism saw a revival at the end of the 1980s, at a time when the Uruguay Round negotiations were a long time in coming to fruition and when free trade agreements were on the upturn. The World Bank (2005) registered the signing of over one hundred such agreements during the 1990s, by virtue of the creation or consolidation of zones of regional integration.

In his examination of the effects that regional groups have on the global trading system, J.Bhagwati (1991) coined the terms building and stumbling blocks in reference to whether the groups were open or closed in character. The author considered regionalism to be discriminatory by nature and to be a cause of perverse effects. Not only liable to trigger interbloc trade wars, it also favors the domination of the smaller states by the larger ones in each entity (J. Bhagwati, 1995). In addition, the complex, tangled network of preferential and free trade agreements referred to as the spaghetti bowl, engender further costs as a result of the different rules of origin involved in multiple membership (J. Bhagwati, D. Greenaway, A. Panagariya, 1998). L. Summers (1991) countered Bhagwati's vision of things by emphasizing that intra-regional liberalization constitutes a step towards multilateralism and that it induces more trade creations than trade diversions. R. Baldwin (2004) found that those nations that were the most fervent advocates of GATT were also assimilated into regional blocs, and that the new wave of trade regionalism did not impede the conclusion of the Uruguay Round agreements.

In Bhagwati's approach (1991), a regional group constitutes a building block when it favors multilateralism and a stumbling block when it acts as an obstacle to it. From the point of view 
of international trade, an agreement will have globalizing effects if it generates not only an internal trade flow but also the movement of trade with the rest of the world. In this article, we consider whether the large groups created or renewed since the end of the 1980s have indeed contributed to an upsurge in multilateral trade and can therefore be deemed building blocks. Regionalism will be considered only in terms of trade, in accordance with the definition adopted by the WTO.

The use of a gravity model is particularly well adapted to this objective. Since the initial studies carried out simultaneously by J. Tinbergen (1962) and P. Pöyhönen (1963), and then taken further by H. Linnemann (1966), gravity models have been used more and more by analysts of international trade. They provide a cogent explanation of bilateral trade flows, positively by the size of partner economies, and negatively by the geographical distance separating them, this distance being retained as the proxy for transport costs. Dummy control variables for the effect of regional agreements can be added to the basic equation. In this way, the additional trade attributable to the formation of a free trade area or a customs union can be determined in relation to the gravitational norm. Through the introduction of a set of three regional variables per agreement, it is possible to test simultaneously the effects of the groupings for intra-bloc trade, extra-bloc exports and extra-bloc imports. Such estimates require the use of panel data to check for potential unobservable factors that are specific to each pair of countries and which will have an influence on trade. S. Baier and J. Bergstrand (2005) demonstrated that the absence of checks on the heterogeneity of pairs introduces a bias into the regional coefficient values.

In order to evaluate the effects of the blocs that appeared or re-emerged during the new wave of regionalism, we use, for the period 1986-2005, a gravity model with panel data, comprising 
sets of three regional dummy variables. In respect of the earlier gravity approaches dealing with trade regionalism, listed in an OECD Working Paper (2001), in R. Adams et al. (2003) and in M. Cipollina and L. Salvatici (2007), we concern ourselves with the following points:

- With the aid of the two extra-regional coefficients, we highlight the potential surplus of export and/or import trade generated by the formation of the groups examined. A positive coefficient signals what, in a new terminology, will be called an external creation of exports and/or imports. We consider as building blocks those groups for which the sum of the two parameters is positive.

- We establish a typology for trade creations / diversions and building / stumbling blocks identifiable from a gravity model with three regional coefficients, in accordance with their respective signs and values.

- So as to be able to judge the whole, we present a specification of the model which features a single set of three dummies, representing all the intra- and extra-bloc flows, for all groups. To the best of our knowledge, this specification has not as yet been tested within the framework of an approach comprising a gravity model with panel data using three regional variables.

Within the limits of the available data in the UN-COMTRADE database, we select the principal regional agreements from the 1980s and 1990s, that is, those having either a large cumulative GDP or a large number of participants. Two categories of agreement are considered. The first are those that involve a deepening of a pre-existing integration process. The second are those agreements establishing a new grouping. Developing countries are implicated in both categories. At the same time, they implement trade reforms that integrate them into the multilateral system, which is one of the characteristics of "new regionalism" 
(W.Ethier, 1998). A. Estevadeordal et al. (2001) gave an illustration of this for the specific case of Mercosur (Southern Common Market).

In the first category, the European Community, through the introduction of a single market in 1987, achieved one of the objectives of the Treaty of Rome by eliminating the remaining obstacles to the free movement of goods. CACM (Central American Common Market), created in 1960, put in place a customs union, the functioning of which was disrupted at the end of the decade by geopolitical tensions. It was only in 1992 that the Central American states reinstated the union with the Guatemala Protocol. Similarly, the Andean Pact customs union ${ }^{1}$ (1969), for which the rate of tariff reductions had not been in line with expected timescales, was renewed in 1991 with the Barahona Agreement. In the second category, the agreements are either between developing countries or between developing and industrialized countries. NAFTA (North American Free Trade Association) and AFTA (Asean Free Trade Area) initiated their free trade zones in 1994 and 1993 respectively. Mercosur formed itself into a customs union with the Treaty of Asunción in 1991.

All the blocs chosen for the study implemented a liberalization covering all goods, with some having removed non-tariff barriers. Even though there are exceptions for some sensitive products, these do not consist of simple preferential arrangements where tariff reduction is incomplete and/or limited to certain sectors. Other groups created in the 1990s, such as the Southern African Development Community (1992) or the South Asian Preferential Trade Agreement (1996), did not immediately commit to a complete intra-bloc liberalization. For reasons of homogeneity, should the data have been available, it would have been incorrect to include these in our estimate. The Gulf Cooperation Council (1983) established a generalized

\footnotetext{
${ }^{1}$ The Andean Pact became the Andean Community of Nations (ACN) in 1997.
} 
free trade area. However, in the absence of exhaustive data for the majority of its members for the period 1986-2005, we cannot include it in the study.

While it is not a trade agreement per se, the EMU (Economic and Monetary Union) nonetheless exerts an influence on the intra- and extra-bloc trade of its members. It is, therefore, appropriate to assign a set of dummy variables to it. This enables us to verify, for this particular case, the theory that a single currency is a positive factor in trade between the countries having adopted it (J. Frankel and A. Rose, 1998).

The second section of our analysis retraces gravity approaches to regionalism in demonstrating their evolution since the pioneering work of N. Aitken (1973). In the third section we will describe the data, the variables used and the specifications of the model we are adopting. Our results will be presented in the forth section of the paper and will be interpreted with regard to the typology of trade creations / diversions and building / stumbling blocks. The last section concludes.

\section{The Impact of free trade agreements in gravitational approaches}

Since the beginning of the 1970s, the spread of work measuring the impact of free trade agreements on trade has gone hand in hand with an evolution in the method used to evaluate it. The addition of a second and then third regional dummy variable in a gravity equation has refined both the interpretation of results and of trade creation and diversion effects. In studies carried out subsequent to the emergence of these two concepts (J. Viner, 1950), trade creations and trade diversions were measured by comparing the differences between observed flows and theoretical flows - an "anti-monde" without regionalism (B. Balassa, 1975). In the models 
which interest us, the "anti-monde" becomes the gravitational norm around which the effects that groupings have on trade are evaluated.

Most studies carried out thus far have involved cross-sectional or pooling estimates, which do not consider individual effects in each pair of partner countries. Panel data analyses taking into account these specific effects have appeared only recently. In this section we will specify each time we refer to a study involving panel data. That said, all the results we cite are significant.

\section{2-1 Studies involving a single regional dummy}

A first series of estimates dealing with large integrated groups uses only one regional dummy $\left(D_{1}\right)$, to test trade between its member countries. On the whole, they attest to an effect both positive and significant. In taking up a model like the ones used by J. Tinbergen (1962) and H. Linnemann (1966) in conjunction with cross-sectional data (1961), N. Aitken (1973) showed that trade between EEC members (European Economic Community) is five times higher than it would have been had the EEC not been created $^{2}$; this multiplicative factor of intra-bloc trade is only 1.2 in the case of EFTA (European Free Trade Association). Contrary to this, but for the year 1965, J. Bergstrand (1985) estimated that intra-EFTA trade was multiplied by 2, while intra-EEC trade was multiplied by 1.3 . J. Frankel, E. Stein and S. Wei (1995), found the EEC result slightly higher in 1990. D. Greenaway (2000) reached the same multiplicative factor as did Bergstrand for the European Community, but for the whole of the period 1965-1993 and

\footnotetext{
${ }^{2}$ The $\log$ - $\log$ character of the gravity equation allows this type of interpretation from a coefficient $\alpha$ of $D_{l}$. In subtracting member by member the initial equation and the same equation without the regional variable (with an associated trade flow $T_{i j}^{\prime}$, we obtain: $\alpha=\ln \left(T_{i j}\right)-\ln \left(T_{i j}{ }_{i j}\right)$, or $\exp (\alpha)=T_{i j} / T_{i j}$, i.e. the ratio of intra-bloc trade with and without agreement. Ceteris paribus, the exponential of the coefficient of the dummy variable is thus equal to the multiplicative factor of trade. As for N. Aitken, exp $(1.6)=4.95$.
} 
using country-specific effects panel data. Following the same method, L. Fontagné and S. Zignago (2007) obtained a figure of 2.4 for the period 1976-2000.

In the two latter studies, the results found for EFTA diverge noticeably, with figures of 1.2 and 2.7 respectively, whereas the estimate by M. Bussière, J. Fidrmuc and B. Schnatz (2005), using specific effects panel data, produces an intermediate result. NAFTA oscillates between a stimulation that is relatively weak (I. Cheng and H. Wall, 2005, Bussière et al., 2005) and one that is strong (Fontagné and Zignago, 2007) for trade between Canada, the United States and Mexico. Similarly, the studies already cited as using panel data, including those on some Latin American groups display, with varying intensity, the positive influence that Mercosur and the Andean community have on intra-bloc trade. C. Carrillo and C. Li (2004) found a multiplicative factor of about 1.6 for intra-ACN trade. Differences in results between authors are due not only to the distinct periods of analysis but also to the presence or absence of explanatory variables, such as "relative distance", the importance of which we will highlight later.

\section{2-2 Studies involving 2 or 3 regional dummies}

In the work carried out using a single regional dummy, the specification gives no indication of the nature of the additional trade recorded relative to the gravitational norm: it could be either pure trade creation or a trade diversion, or it could be both at the same time. The addition of a second variable $\left(D_{2}\right)$ allows trade between bloc member countries and the rest of the world to be tested. The variable is introduced into those models seeking to explain bilateral trade in its entirety (i.e. imports plus exports). It takes the value 1 if one of the two countries is a bloc member and the other is not, otherwise it takes the value 0 . In the case where the positive 
coefficient of $D_{1}$ is superior to the absolute value of the negative coefficient of $D_{2}$, one part of the additional internal trade corresponds to trade creation and the other to trade diversion, that is to say, a flow of goods substitutes for trade with the rest of the world. As was the case with the initial studies evaluating the effects of the EEC from both observed and theoretical flows, this method of evaluation does not take into account production costs. These latter remain basic to the concepts of trade creation and diversion as defined by J. Viner. To be able to conclude a positive effect in terms of welfare when trade creations exceed trade diversions, it is necessary to make the hypothesis that the former corresponds to a reduction in the unit cost for the importer.

The analyses on the effects of regionalism comprising two dummy variables per agreement rarely attest to concurrent trade creation and diversion. Only T. Bayoumi and B. Eichengreen (1997) identify this scenario for the European Community, as do J. Frankel (1997) for NAFTA, and J. Gilbert et al. (2001) for the Andean Community and Mercosur. The case most frequently encountered is that of trade creation occurring at the same time as a trade diversion qualified as negative (the $D_{1}$ and $D_{2}$ coefficients being positive). This diversion may be pronounced, as in Frankel (1997) and Q. Li (2000) for AFTA, and in D. Greenaway (2000) for AFTA and the European Community. It may be negligible as in the specific effects panel study carried out by J. Lee and I. Park (2005) for NAFTA, the CACM, the ACN and the EU (European Union).

The $D_{2}$ variable tests all bilateral trade with third-world countries. Where trade diversion is negative, the estimates are then not able to indicate whether the agreements have had an effect on extra-bloc exports or extra-bloc imports. Where trade diversion is positive, they do not indicate whether internal flows replace extra-regional exports or imports. The most recent 
studies palliate this deficiency. They seek to explain the export flows of a country i towards a country $\mathrm{j}$ by differentiating the effects of agreements on exports to the rest of the world $\left(D_{X}\right.$ variable) from their impact on imports coming from the rest of the world ( $D_{M}$ variable). This identifies positive diversions of exports or imports (a positive coefficient for $D_{1}$ superior in absolute value to the negative coefficient of $D_{X}$ or of $D_{M}$ ), or a negative diversion (a positive coefficient of $D_{X}$ or of $D_{M}$ ). In welfare terms, if we assume that production costs in the zone are superior to those of the rest of the world, positive import diversions are detrimental in that they induce a less efficient allocation of resources.

As long as the coefficients of $D_{X}$ and $D_{M}$ are negative and each one exceeds the positive coefficient of $D_{1}$ in absolute value, we find ourselves faced with a dilemma. It is impossible to know whether the additional internal trade due to the formation of a regional grouping replaces extra-zone exports or imports. The specific effects estimates carried out by C. Carrère (2004) thus present, for the case of the ACN, coefficients of imports and exports close to -1 and a coefficient representing intra-zone trade equal to 0.6. This aspect, not addressed in the earlier studies, will be dealt with here when we classify creations and diversions in function of the signs and values obtained for the three coefficients.

Some studies introducing three regional dummy variables denote the presence of negative diversion of imports and exports while others denote positive diversions. In R. Elliot and K. Ikemeto (2004), and in the individual effects panel study undertaken by N. Kien and Y. Hashimoto (2005), AFTA recorded negative diversions of imports and exports. The same was true for the European Community during the implementation of the Single Market (M. Endoh, 1999, Elliot and Ikemeto, 2004). For Mercosur, the import diversions are positive for I. Soloaga and L. Winters (2001), E. Croce et al. (2004) and in the model of specific effects 
presented by P. Tumbarello (2007), but they are negative in N. Kien and Y. Hashimoto (2005). ACN's export diversions are mainly negative whereas those of NAFTA are positive (Elliot and Ikemeto, 2004, Kien and Hashimoto, 2005).

\section{Data, variables and variants of the model}

Following on from the work involving three regional dummy variables, we evaluate the effects of the principal free trade agreements of the 1980s and 1990s. The choice of the SITC2 (Standard International Trade Classification Revision 2) version of the COMTRADE database allows us to go back as far as 1986 with complete data concerning bilateral exports for 50 developed and developing countries. The list of countries appertaining to the groups under consideration is to be found in Appendix $1^{3}$. The agreements concerning the American continent bring together all their member countries, including those of the CACM, rarely considered in the earlier studies. With the exception of Hungary and Poland, the new members of the EU are not included due to a lack of exhaustive data for the whole of the period under study. The same is true for Burma, Brunei, Cambodia and Laos for AFTA. In all, the model detailed below explains $50 \times 49$ export flows from one country to another, which, when multiplied by the 20 years represented, gives a total of 49000 observations.

\footnotetext{
${ }^{3}$ Ten countries make up the sample without belonging to a group being estimated: Australia, China, South Korea, Hong-Kong, India, New Zealand, Norway, Japan, Switzerland, Turkey.
} 


\section{3-1 The choice of variables}

Just as it was developed in its most simple form by J. Tinbergen (1962) and H. Linnemann (1966), the gravity equation makes bilateral trade flows $(T)$ dependent upon the product of the incomes $(Y)$ of the two partner countries $\mathrm{i}$ and $\mathrm{j}$, divided by the distance separating them $(D)$ :

$T_{i j}=A \frac{Y_{i}^{\beta_{1}} Y_{j}^{\beta_{2}}}{D^{\beta_{3}}{ }_{i j}}$

Where $A, \beta_{1}, \beta_{2}$ and $\beta_{3}$ are the parameters to be estimated.

Using a log-linear form that allows interpretation of the coefficients as elasticities of trade flow with regard to the explanatory variables, we obtain:

$\ln \left(T_{i j}\right)=\alpha+\beta_{1} \ln \left(Y_{i}\right)+\beta_{2} \ln \left(Y_{j}\right)-\beta_{3} \ln \left(D_{i j}\right)$

This gravity equation is considered as one of the most stable and the most robust empirical relations in economics (T. Mayer, 2001). The main criticism leveled at it initially concerned its lack of theoretical foundations, being a simple intuition derived from the physical forces of attraction and repulsion. By introducing transport costs into the model of monopolistic competition, P. Krugman (1980) countered this by arriving at a demand equation close to the gravity equation. Following J. Anderson (1979) and A. Deardorff's lead (1995), other authors demonstrated that the neoclassical model of international trade is also compatible with the basic gravity model. J. Bergstrand (1989) answered those who questioned the duplicity of the explanations. In developing a general equilibrium model based on two factors and two goods, one being homogenous and the other differentiated, he showed that the gravity model could be adapted to a framework of analysis mixing traditional and intra-industry specializations. 
Empirically, it is possible to bring in variables that are sensitive to specialization type. The absolute value of the difference in per capita GDP is used to test differences in factor endowment. A positive sign for its coefficient reflects traditional trade, inter-industrial in nature. A negative sign favors the thesis of Linder (1961), which puts a rapprochement of income per capita as one of the determinants of intra-industry trade (J. Frankel, 1997). Linder's hypothesis of the similarity of structures of national demand can be even better tested by the addition of a similitude of GDP variable.

As did B. Baltagi et al. (2003) and L. De Benedictis et al. (2005), we bring in both of the variables described above ( $p c G D P$ dif and SIMIL), adopting the following measures for two partners $\mathrm{i}$ and $\mathrm{j}$ (using $\mathrm{IMF}^{4}$ data for GDP and per capita GDP):

$$
\begin{aligned}
& p_{c G D P d i f}=\ln \left|\frac{G D P_{i}}{P O P_{i}}-\frac{G D P_{j}}{P O P_{j}}\right| \\
& \text { IMIL }_{i j}=\ln \left[1-\left(\frac{G D P_{i}}{G D P_{i}+G D P_{j}}\right)^{2}-\left(\frac{G D P_{j}}{G D P_{i}+G D P_{j}}\right)^{2}\right]
\end{aligned}
$$

Another question requiring examination is that of the choice of distance variable, distance being a proxy for transport costs. Caution is advised in its interpretation. The majority of studies use the geodesic distance between the political capitals of the partner countries, or between their economic capitals (the approach we have retained). This distance corresponds to the "great circle" measurement calculated from the latitudes and longitudes of the selected towns. However, transport network infrastructures do not follow a course as the crow flies and

\footnotetext{
${ }^{4}$ IMF World Economic Outlook, April 2007.
} 
they bypass natural obstacles such as mountain ranges. The journey in kilometers may therefore be underestimated in the gravity equation. This is a case in point for the Andean Community of Nations, regarding land-based transport alone. The distance factor can equally be over-estimated, however, when there is a great deal of cross-boarder trade, as is a current situation in West Africa. In the end, transport costs are not purely a factor of distance. Other elements such as unloading and customs clearance fees or insurance premiums are also involved and are not necessarily correlated with distance in kilometers.

Once the absolute distance between two countries has been controled, it is advisable to also take into account relative distance, i. e. that separating them from their other partners. Trade is, in fact, more intense between a pair of countries that are remote from the world's largest economic centers than it is between two economies that are geographically close to them. We would therefore expect Australia and New Zealand to trade between themselves to a greater extent than would Austria and Portugal, even though the geographical distances between the two countries in each pair are similar. A. Deardorff (1995) was the first author to bring the relative distance variable into a gravity model. J. Polak (1996) and J. Harrigan (2001) showed the existence of an important bias when only the absolute distance variable was considered. J. Polak emphasized that the most biased coefficients were precisely those that measured the effects of trading blocs. His reasoning was based on some surprising results found in the studies by Frankel, Stein and Wei (1994 and 1995). Undertaken without the relative distance control, the studies indicate in particular the absence or low level of trade creation within the EEC. 
As did S. Wei (1996), we will measure the relative distance of a country $\mathrm{k}\left(R E M O T_{k}\right)$ by the sum of the distances separating it from a partner 1, weighted by the size of l's GDP in the total world GDP $\left(G D P_{\text {World }}\right)$ : $R E M O T_{k}=\sum_{l}\left(D I S T_{k l} \times \frac{G D P_{l}}{G D P_{\text {World }}}\right)$

The relative distance variable retained in our equation for the couple $(\mathrm{i}, \mathrm{j})$ is the logarithm of the average of the relative distances of the countries $i$ and $j$.

We also add the logarithm of the real bilateral exchange rate to the estimate, which brings a price variable into the model. Initiated by J. Bergstrand (1985), this practice allows the evolution of competitiveness to be tested (T. Bayoumi and B. Eichengreen, 1997). We calculate the real exchange rate ${ }^{5}$ from the nominal exchange rate and consumer price index data taken from the IMF (see Appendix 2). The other explanatory variables are dummies. The sharing of a common border $(C O N T I G)$ is likely to positively influence bilateral trade. The same is true of sharing a common language $(L A N G)$, which is a proxy of cultural closeness and brings about a reduction in trade transaction costs. Finally, we introduce a set of three dummies representative of the exchange flows of the member countries of all the Regional Trade Agreements (RTA variables).

\footnotetext{
${ }^{5}$ The formula used for the calculation of real exchange rate $\left(\mathrm{RER}_{\mathrm{ij}}\right)$ is the following: $R E R_{i j}=N E R_{i j} \times \frac{C P I_{j}}{C P I_{i}}$, where:

$\mathrm{NER}_{\mathrm{ij}}$ is the annual average indirect nominal value of country i's currency expressed in country j's currency

$\mathrm{CPI}_{\mathrm{j}}$ is the annual average consumer price index of country $\mathrm{j}$

$\mathrm{CPI}_{\mathrm{i}}$ is the annual average consumer price index of country $\mathrm{i}$
} 


\section{3-2 The gravity equations estimated}

Using model (2) as its basis and giving a temporal dimension to most of the variables, the equation becomes:

$$
\begin{aligned}
\ln \left(X_{i j t}\right)= & \alpha+\beta_{1} \ln \left(G D P_{i t}\right)+\beta_{2} \ln \left(G D P_{j t}\right)+\beta_{3} \ln \left(D I S T_{i j}\right)+\beta_{4} \ln \left(\text { REMOT }_{i j t}\right)+\beta_{5} \ln \left(\text { pcGDPdif }_{i j t}\right) \\
& +\beta_{6} \ln \left(\text { SIMIL }_{i j t}\right)+\beta_{7} \ln \left(R E R_{i j t}\right)+\beta_{8} C O N T I G_{i j}+\beta_{9} L A N G_{i j} \\
& +\beta_{10} R T A_{-} \text {intra }_{i j t}+\beta_{11} R T A_{-} X_{i j t}+\beta_{12} R T A_{-} M_{i j t}+\varepsilon_{i j t}
\end{aligned}
$$

We define a second specification based on the equation (3), by adding to it a series of 20 dummies corresponding to each of the years of the period under study. For reasons of simplification, we have not included these in the summary table (cf. Table 1). The first RTA variable tests intra-bloc trade. It takes the value 1 if the two countries $\mathrm{i}$ and $\mathrm{j}$ have signed the same agreement, and 0 otherwise. The second variable measures the impact of the groupings on those exports destined for the rest of the world. It takes the value 1 if country $i$ is party to an agreement to which country $\mathrm{j}$ is not, and 0 otherwise. The third variable captures the effects on imports coming from the rest of the world. It takes the value 1 where $\mathrm{i}$ does not belong to the group of which $\mathrm{j}$ is a member, and 0 otherwise.

The equation specification (3) comprising the three $R T A$ variables will allow us to give an overall evaluation of the process of regional integration vis-à-vis multilateral trade. That said, however, we will use the following formulation to interpret the results detailed for each agreement: 


$$
\begin{aligned}
\ln \left(X_{i j t}\right)= & \alpha+\beta_{1} \ln \left(G D P_{i t}\right)+\beta_{2} \ln \left(G D P_{j t}\right)+\beta_{3} \ln \left(D I S T_{i j}\right)+\beta_{4} \ln \left(R E M O T_{i j t}\right)+\beta_{5} \ln \left(p c G D P d i f_{i j t}\right) \\
& +\beta_{6} \ln \left(S I M L_{i j t}\right)+\beta_{7} \ln \left(R E R_{i j t}\right)+\beta_{8} C O N T I G_{i j}+\beta_{9} L A N G_{i j}+\beta_{10} A C N_{-} i n t r a_{i j t}+\beta_{11} A C N_{-} X_{i j t} \\
& +\beta_{12} A C N_{-} M_{i j t}+\beta_{13} A F T A_{-} i n t r a_{i j t}+\beta_{14} A F T A_{-} X_{i j t}+\beta_{15} A F T A_{-} M_{i j t}+\beta_{16} C A C M \_i n t r a_{i j t} \\
& +\beta_{17} C A C M_{-} X_{i j t}+\beta_{18} C A C M_{-} M_{i j t}+\beta_{19} E U_{-} i n t r a_{i j t}+\beta_{20} E U_{-} X_{i j t}+\beta_{21} E U_{-} M_{i j t}+ \\
& \beta_{22} E M U_{-} i n t r a_{i j t}+\beta_{23} E M U_{-} X_{i j t}+\beta_{24} E M U_{-} M_{i j t}+\beta_{25} M E R C_{-} i n t r a_{i j t}+\beta_{26} M E R C_{-} X_{i j t} \\
& +\beta_{27} M E R C_{-} M_{i j t}+\beta_{28} N A F T A_{-} i n t r a_{i j t}+\beta_{29} N A F T A_{-} X_{i j t}+\beta_{30} N A F T M_{-} M_{i j t}+\varepsilon_{i j t}
\end{aligned}
$$

The regional dummies are constructed according to the method used for the RTA variables, but are customized for each of the seven groups. In the cases where the agreement has yet to be implemented, there is no member country and the variables take the value 0 . For a founder member, the method is applied from the year of the agreement's coming into force, and for a new member, from that of its joining. The years in which the agreements were implemented, and the dates of their enlargement are shown in Appendix 1. The period for assessing the impact of the Single Market runs from 1987 to 1998 , enabling the majority of its effects ${ }^{6}$ to be taken into account, and allowing the testing of the implementation of the EMU from 1999 onwards whilst avoiding a correlation between the dummy variables.

\section{Trade effects of regional integration}

\section{4-1 The estimate results}

The results of the three estimates are presented in Table 2. The first evaluates the intra and extra-bloc effects of the groupings with the regional trade agreement variables (RTA model (1)). Fischer's Test shows the presence of specific effects. Thus, factors that are unobservable

\footnotetext{
${ }^{6}$ By 1998 more than $80 \%$ of directives regarding the implementation of the Single Market had already passed into national law of the member countries; when we transposed this statistic to 14 of the 15 member states, the figure reached 90\% (European Commission, Tableau d'affichage du Marché unique, $\mathrm{n}^{\circ}$ 2, May 1998).
} 
and unchanging over time and that are specific to each couple of partner countries, for example historical, cultural, geopolitical or geographical, will have an influence on trade flows. The advantage of using country-specific effect models is that it enables this heterogeneity to be taken into account. Moreover, not carrying out a check for unobservable factors would bring in a bias in the regional dummy coefficients. In the study by L. Fontagné and S. Zignago (2007), the multiplicative factor of intra-bloc trade diminishes by more than half when these factors are included. We continue the econometric process with a Hausman Test. This shows that the specific effects of the RTA model (1) are fixed and non-random.

The second estimate (RTA model (2)) adds dummy variables representing the years for the period under study to the first model. The coefficients for these 20 variables are all positive and significant. Comparison of models (1) and (2) with their corresponding Fischer statistics, however, indicates that the first has a better global signification than the second. It is the first estimate that we retain for the interpretation of results, therefore. The third estimate (model (3) of Table 2) is identical to the first, the only exception being that it tests the trade agreements in a detailed manner and not as a whole. Its results will allow us to extract the creations and diversions of trade for the different groups and to determine if they constitute building or stumbling blocks.

The inconvenience of country-specific effects is that they capture variables that are stable over time, and which can no longer be separately estimated, therefore. In our case, these are variables of contiguity, common language and of distance. In practically all of the studies undertaken, the corresponding coefficients are significant, positive for the first two and negative and close to one for the third (T. Mayer, 2001). To estimate them separately would add nothing to our purpose, which is to do with regional variables. These latter change over the period 1986-2005, as the start of the implementation of agreements always takes place during 
that period. In addition, certain groups have been subject to enlargement (Mercosur ${ }^{7}, \mathrm{EU}$, EMU), in itself a further source of variation over time.

In accordance with the traditional results of estimates on gravity models, the size of partners as reflected by their GDP has a tangible and very significant effect on their trade. The coefficient of the real bilateral exchange rate, on the other hand, proves to be low and its sign contraintuitive. Relative distance stands out as being significant and highly explanatory of trade, confirming its necessary inclusion in such an equation. The variable indicating the difference in per capita GDP acts negatively. This follows Linder's thesis, since trade diminishes in proportion to the increase in the difference in per capita income, but this effect is minimal due to the fact of a reduced coefficient. Moreover, the rapprochement of the absolute GDPs does not stimulate bilateral trade. On the contrary, the negative sign of the SIMIL variable reveals that trade intensifies in relation to the divergence in GDPs.

Through the results given by the three dummy variables for the regional trade agreements, we are in a position to give an overall judgment on the new wave of regional integration. In the best specification of the model (1), it stimulates equally both intra and extra-bloc trade. Intrabloc trade is $39 \%$ higher than without regionalization, and exports and imports with the rest of the world are $16 \%$ and $20 \%$ higher, respectively. Since the end of the 1980 s, the formation or consolidation of large regional groups has not only been of benefit to their internal trade flows but has also been a generator of multilateral trade.

This first conclusion is verified and detailed, case by case, in the model (3) estimates. Let us examine the parameters of the intra-bloc dummies: they all come out significant and positive.

\footnotetext{
${ }^{7}$ Mercosur enlarged by the creation of a free trade area with Chile (1996) and with Bolivia (1997).
} 
An average of the coefficients found in the previous studies, irrespective of method used and period studied, features in the meta-analysis of M. Cipollina and S. Salvatici (2007). Our estimates correspond to a quarter of that average for the EU, a third for the CACM, half for AFTA, NAFTA and Mercosur, and slightly below the average for ACN. It is logical that we should obtain lower coefficients as practically none of the studies included in the meta-analysis take the unobservable factors into account. The EU's weak internal coefficient seems to suggest that the constitution of the Single Market is less propitious to the development of commercial interdependence than was the EEC. The results for the two South American customs unions attest to ACN having a greater influence on intra-bloc trade than does Mercosur. The beginning of the period chosen for the Andean Community, however, corresponds to the adoption of a short timescale for the implementation of the customs union, even though it was already partially in operation between Argentina and Brazil before the signing of the Treaty of Asunción. Comparable to that of Mercosur, the impact of CACM's customs union allowed it to return to having the degree of intra-regional trade reached at the beginning of the 1980s (O. Dabène, 1998). The intermediary results for NAFTA and AFTA emphasize that their status as a free trade zone does not constitute a discriminatory criterion with regards to other modes of integration.

We also test the effects of the European single currency on the trade of the EMU member countries for the period 1999-2005. J. Frankel and K. Rose were the first to put forward the idea that monetary union optimality is achieved in an endogenous manner. Through empirical studies, they show that the use of a common currency is at the heart of a reinforcement of trade links (A. Rose, 2000), this being a factor for better synchronization of business cycles (J. Frankel and A. Rose, 1998). The first proposition can be verified in the case under study, since the trade between members of the Eurozone would be $16 \%$ higher than it would have been had the single currency not existed. Our result extends the almost identical ones of A. Micco et al. 
(2003) and H. Flam and H. Nordstrom (2003), whose study periods only cover four years of the EMU's lifetime. Their results are also obtained from a fixed specific effects panel, but involve around twenty industrialized countries only.

\section{4-2 Do the groups generate trade creations / diversions and do they constitute building or stumbling blocks?}

Using the sets of intra and extra-bloc coefficients obtained in the model (3) as our basis, we are now going to determine the trade creations / diversions imputable to the different groups, asking ourselves if they constitute building or stumbling blocks. First of all, we draw up a typology of the creations / diversions identifiable from a gravity model using 3 regional variables, as well as a typology of the trading blocs (Tables 3 and 4).

The first table presented, links the designation of each category of creation and diversion to the corresponding trade effects. The second configures these in function of the respective signs and values of the intra-bloc $\left(\mathrm{d}_{1}\right)$ and extra-bloc $\left(\mathrm{d}_{\mathrm{X}}\right.$ and $\left.\mathrm{d}_{\mathrm{M}}\right)$ coefficients. Let us consider the situation where $d_{1}$ is higher than zero with a positive $d_{X}$ and/or $d_{M}$. In previous studies this has sometimes been qualified as a negative export and/or import diversion. Instead, we substitute the expression "trade creation of exports and/or imports", which better describes the boosting effect these new groups have on multilateral trade.

As long as $d_{X}$ and $d_{M}$ are positive, the group constitutes a building block. If they are negative, it is a stumbling block. When the sum of $d_{X}$ and $d_{M}$ is positive with one of the two coefficients being negative the group constitutes a building block, the extent of export creations being superior to the fall in imports, or import creations exceeding the reduction in exports. The few studies that draw up a net balance of trade resulting from integration do so from the three 
regional variables. Only P. Tumbarello (2007) systemizes the summation of the three coefficients to all the groups under examination. However, there remains the risk of considering as building blocks those groups which favor trade between member countries while destroying multilateral trade $\left(d_{1}>\left|d_{X}+d_{M}\right|\right.$ with negative $d_{X}$ and $\left.d_{M}\right)$. It is for this reason that we draw up the net trade balance from the two extra-regional coefficients.

It should be noted that trade diversions occur to the extent that an intra-bloc trade flow may replace an extra-bloc flow. With two extra-regional variables, the designation of the type of diversion may prove to be problematical. When the two external coefficients are negative and their sum is higher in absolute value than the internal coefficient (last line of Table 4), it is impossible to determine the respective proportion of export and import diversion, or even the presence of one or the other when $\left|d_{X}\right|$ and $\left|d_{M}\right|$ are both superior to $d_{1}$.

Let us now examine Table 2's results of the model (3) in the light of the interpretative framework given in Table 4. No regional group induces an import trade diversion. With the exception of NAFTA, no group is the source of an export diversion. All the groups give rise to import trade creations and, for six out of the seven, to export trade creations. In every case, the balance of the two extra-bloc effects of the bloc formation is positive. Our results, therefore, place each one as a building block, favorable to both trade regionalization and globalization.

The work of N. Kien and Y. Hashimoto (2005) is well suited for comparison as it includes a period of study and a number of countries close to our own. Moreover, it identifies specific fixed effects in a panel estimate. The signs and values of the coefficients for NAFTA indicate here also the presence of export trade diversions. Observation of the figures for the North American countries would tend to suggest that these diversions concern the agricultural and 
mining sectors ${ }^{8}$. As for AFTA, the two authors present results equally close to our own, in particular for the values for the intra-bloc and export coefficients. Trade between AFTA members would be 1.7 higher than it would have been had the bloc not been created, and sales to the rest of the world would be almost doubled. This vigorous export trade, which goes hand in hand with the stimulation of internal trade, is to be found in all the groups making up the model (3), although to a lesser degree and with the exception of NAFTA.

The dynamic effects of regional integration are frequently put forward to explain the simultaneous growth of intra-bloc trade and exports to the rest of the world. The creation of regional markets gives rise to increased competition, encourages innovation and allows the achievement of economies of scale, in accordance with mechanisms developed for the European Community in the first Emerson Report (M. Emerson et al., 1990). The new regionalism is accompanied in every case by a gradual decrease in customs duties and consequently adds an international element to the new competition. In the developing countries, the implementation of new groupings coincides with open trade reforms and the politics of attracting direct foreign investment. This justifies the expression "open regionalism" often used by the Economic Commission of United Nations for Latin America (ECLAC, 1994).

Taking as a starting point the $\mathrm{CHELEM}^{9}$ database, we can observe that the sectors where internal trade and external sales increase concurrently are mainly those reputed to have strong potential for economies of scale. Included here ${ }^{10}$ are organic chemical and plastic products for

\footnotetext{
${ }^{8}$ Since NAFTA's inception, exports of animal feed (United States), cereal (United States, Canada) and refined petrol (Mexico) declined towards the rest of the world but increased towards partner countries (observations made by the author based on data from the CHELEM database - cf. note 9).

${ }^{9}$ The CHELEM database (Comptes Harmonisés sur les Echanges et l'Economie Mondiale) of the CEPII (Centre d'Etudes Prospectives et d'Informations Internationales) proposes a breakdown of 71 product categories.

${ }^{10}$ This description does not concern CACM countries, which are not represented in CHELEM's trade data.
} 
all the groups, vehicles and automobile components for all groups excepting the ACN, the aeronautical industry and pharmaceuticals for the EU, and refined petrol for Mercosur and the ACN. Electronic components and computer and telecommunications equipment are sometimes represented, more particularly for the Philippines, Malaysia, Thailand and Singapore. The AFTA countries benefit from a dense network of multinational firms that have undertaken efficient reorganization of their production so as to favor internal liberalization (M. Fujita, 2001). In facilitating the intra-bloc division of work between subsidiaries, trade regionalism acts as a vector of competitiveness on a multilateral scale. In one of his conclusions, W. Ethier (1998) underlines that the attraction of direct investments exerted by the creation of large regional markets constitutes a means by which the emerging countries enter into competition with the aim of integrating themselves into the multilateral system.

\section{Conclusion}

Our panel data estimate using a gravity model comprising three regional dummies ends with convergent conclusions. Integration stimulates the intra-bloc trade of member countries, as it does their extra-bloc exports and extra-bloc imports. This general result is found to be true from case to case, with the exception of NAFTA, which induces an export trade diversion in substituting sales to the rest of the world with internal flows. The other trading blocs and the EMU all give rise to export trade creations. All the groups display import trade creations. As NAFTA is at the origin of a positive net balance for its trade with the rest of the world, all the groupings constitute building blocks. If the recent wave of regionalism stimulates trade between member countries, it is by the same token a source of trade multilateralization. Moreover, and for AFTA in particular, it seems to favor the insertion of member countries into the world economy, by simultaneously boosting intra-bloc and worldwide export trade. 
The open character of the trading blocs can be seen in their successive enlargements and/or in their participation in projects encompassing vast free trade areas. At the beginning of the 1990s, J. Bhagwati (1993) emphasized that regional groups could only constitute building blocks within the framework of a continual expansion leading them towards global free trade. The theorist behind the "domino effect" (R. Baldwin, 2003) highlights the topicality of this trend (R. Baldwin, 2006). Even before the enlargement of 2004, the creation of the Single Market had an attraction effect on the countries belonging to the European Free Trade Association. On the impetus of China's joining the WTO, the AFTA member countries signed a free trade agreement with it, which in turn set off a series of bilateral negotiations with Japan and South Korea. The free trade agreement project between the United States and Mexico resulted in NAFTA and in the announcement of the Enterprise for the Americas Initiative, and Brazil and Argentina extended their association to include their Paraguayan and Uruguayan neighbors. The creation of the South American Community of Nations (2004) and the opposing negotiations of the Free Trade Area of the Americas nonetheless attest to a wish on the part of Mercosur and ACN members to exploit the dynamic effects of sub-continental integration as a matter of priority. 


\section{References}

Adams R., Dee P., Gali J., McGuire G. (2003) The Trade and Investment Effects of Preferential Trading Arrangements - Old and New Evidence. Productivity Commission Staff Working Paper, Canberra, May

Aitken N. (1973) The Effect of the EEC and EFTA on European Trade: A Temporal CrossSection Analysis. American Economic Review 63: 881-92

Anderson J. (1979) A Theoretical Foundation for the Gravity Equation. American Economic Review 69: 106-116

Baier S., Bergstrand J. (2005) Do Free Trade Agreements Actually Increase Members' International Trade? Manuscript, December

Balassa B. (1975) European Economic Integration. Balassa B. ed., Amsterdam

Baldwin R. (2003) A Domino Theory of Regionalism. NBER Working Paper $n^{\circ} 4465$

Baldwin R. (2004) Stepping Stones or Building Blocks? Regional and Multilateral Integration. Regional Economic Integration in a Global Framework, ECB and People's Bank of China.

Baldwin R. (2006) Multilateralising Regionalism: Spaghetti Bowls as Building Blocks on the Path to Global Free Trade. The World Economy 29: 1451-18

Baltagi B., Egger P., Pfaffermayr M. (2003) A Generalized Design for Bilateral Trade Flows Models. Economic Letters 80: 391-97

Bayoumi T., Eichengreen B. (1997) Is Regionalism Simply a Diversion: Evidence from the Evolution of the EC and EFTA. In Ito T. and Krueger A., Regionalism versus Multilateral Trade Arrangements, NBER, East Asia Seminar on Economics, vol. 6, Chicago: University of Chicago Press

Bergstrand J. (1985) The Gravity Equation in International Trade: Some Microeconomics Foundations and Empirical Evidence. Review of Economics and Statistics 67: 474-81

Bergstrand J. (1989) The Generalized Gravity Equation, Monopolistic Competition, and the Factor-Proportions Theory in International Trade. Review of Economics and Statistics 71: $143-53$

Bhagwati J. (1991) The World Trading System at Risk. Princeton, NJ: Princeton University Press

Bhagwati J. (1993) Regionalism and Multilateralism: An Overview. In De Melo J. and Panagariya A. (eds.), New Dimensions in Regional Integration, 22-51

Bhagwati J. (1995) U.S. Trade Policy: the Infatuation with Free Trade Areas. In The Dangerous Drift to Preferential Trade Agreements, Bhagwati J. and Krueger A. eds, American Enterprise Institute for Public Policy Research, Washington 
Bhagwati J., Greenaway, D., Panagariya A. (1998) Trading preferentially: Theory and Policy. Economic Journal 108: 1128-48

Bussière M., Fidrmuc J., Schnatz B. (2005) Trade Integration of Central and Eastern Countries - Lessons from a Gravity Model. ECB Working Paper Series $n^{\circ} 545$, November

Carrère C. (2004) Revisiting the Effects of Regional Trade Agreements on Trade Flows with Proper Specification of the Gravity Model. European Economic Review 50: 223-47

Carrillo-Tudela C., Li C. (2004) Trade Blocks and the Gravity Model: Evidence from Latin American Countries. Journal of Economic Integration 19: 667-89

Cheng I., Wall H. (2005) Controlling for Heterogeneity in Gravity Models of Trade and Integration. Federal Reserve Bank of St. Louis Review, January-February, 49-61

Cipollina M., Salvatici S. (2007) Reciprocal trade agreements in Gravity Models: a Metaanalysis. Economics and Statistics Discussion Paper, $n^{\circ}$ 35/07, University of Molise, Dept. SEGeS

Croce E., Juan-Ramon V., Zhu F. (2004) Performance of Western Hemisphere Trading Blocs: a Cost-Corrected Gravity Approach. IMF Working Paper n ${ }^{\circ} 109$

Dabène O. (1998) L'Intégration régionale dans les Amériques. Les Etudes du CERI n 45, Centre d'études et de recherches internationales, SciencesPo-CNRS, Paris

Deardorff A. (1995) Determinants of Bilateral Trade: Does Gravity Work in a Neoclassical World? NBER Working Paper $n^{\circ} 5377$

De Benedictis L., De Santis R., Vicarelli C. (2005) Hub-and-Spoke or else? Free trade agreements in the "enlarged" European Union. The European Journal of Comparative Economics 2: 245-60

ECLAC - Economic Commission for Latin America and the Caribbean (1994) Open Regionalism in Latin America and the Caribbean, Santiago, September

Elliot R., Ikemeto K. (2004) AFTA and the Asian Crisis: Help or Hindrance to ASEAN IntraRegional Trade? Asian Economic Journal 18: 1-23

Endoh M. (1999) Trade Creation and Trade Diversion in the EEC, the LAFTA and the CMEA 1960-1994. Applied Economics 31: 207-16

Emerson M., Aujean M., Catinat M., Goybet P., Jacquemin A. (1990) The Economics of 1992: The E.C. Commission's Assessment of the Economic Effects of Completing the Internal Market. Journal of International Economics 28: 385-88

Estevadeordal A., Goto J., Saez R. (2001) The New Regionalism in The Americas: The Case of Mercosur. Journal of Economic Integration16: 180-202

Ethier W. (1998) The New regionalism. The Economic Journal 108: 1149-61 
Flam H., Nordstrom H. (2003) Trade Volume Effects of the Euro: Aggregate and Sector Estimates. Seminar Paper, $\mathrm{n}^{\circ}$ 746, Institute for International Economic Studies, Stockholm University

Fontagné L., Zignago S. (2007) A Re-evaluation of the Impact of Regional Trade Agreements on trade Patterns. Economie internationale 109: 31-51

Frankel J. (1997) Regional Trading Blocs in the World Economic System. Institute for International Economics, Washington D.C.

Frankel J., Stein E., Wei S. (1994) APEC and Regional Trading Arrangements in the Pacific. Washington, D. C.: Institute for International Economics

Frankel J., Stein E., Wei S. (1995) Trading blocs in the Americas: The Natural and Unnatural and the Supernatural. Journal of Development Economics 47: 61-95

Frankel J., Rose A. (1998) The Endogeneity of the Optimum Currency Area Criteria. The Economic Journal 108: 1009-25

Fujita M. (2001) Regional Trade Arrangements and Strategies of Multinationals: Implications of ASEAN Free Trade Agreement (AFTA) for Economic Integration. In Satoru Okuda (ed.), APEC in the 21st Century? Selected Issues for Deeper Economic Cooperation, APEC Study Center, Institute of Developing Economies

Gilbert J., Scollay R., Bora B. (2001) Assessing Regional Trading Arrangements in the AsiaPacific. Policy Issues in International Trade and Commodities Study Series $\mathrm{n}^{\circ} 15$, UNCTAD

Greenaway D. (2000) Multilateralism, Minilateralism and Trade Expansion. In Das D. K. (ed), Asian Exports, Oxford University Press, 115-165

Harrigan J. (2001) Specialization and the Volume of Trade: Do the Data Obey the Laws? NBER Working Paper $n^{\circ} 8675$

Kien N., Hashimoto Y. (2005) Economic Analysis of Asean Free Trade Area - by a Country Panel Data. Discussion Paper in Economic and Business, $\mathrm{n}^{\circ} 12$, Graduate School of Economics and Osaka School of International Public Policy (OSIPP)

Krueger A. (1999) Trade Creation and Trade Diversion under NAFTA. NBER Working Paper $\mathrm{n}^{\circ} 7429$, Cambridge

Krugman P. (1980) Scale Economies, Product Differentiation, and the Pattern of Trade. American Economic Review 70: 950-959

Lee J., Park I. (2005) Free Trade Areas in East Asia: Discriminatory or Non-discriminatory? The World Economy 28: 21-48

Li Q. (2000) Institutional Rules of Regional Trade Blocks and their Impact on Trade. In Switky, R., Kerremans, B. (eds.), Political Consequences of Regional Trade Blocs, London: Ashgate, 85-118 
Linder S. (1961) An Essay on Trade and Transformation. New York: John Wiley

Linnemann H. (1966) An Econometric Study of International Trade Flows. Amsterdam: NorthHolland

Mayer T. (2001) National Borders Matter... But Les and Less. La Lettre du Cepii $\mathrm{n}^{\circ} 207$, December

Micco A., Stein E., Ordonez G . (2003) The Currency Union Effect on Trade: Early Evidence from EMU. Working Paper $n^{\circ}$ 490, Research Department, Inter-American Development Bank

OECD (2001) Regional Integration: Observed Trade and Other Economic Effects. Working Paper $\mathrm{n}^{\circ}$ 19, Trade Committee, M. Geloso Grosso, October

Polak J. (1996) Is APEC a Natural Regional Trading Bloc? A Critique of the Gravity Model of International Trade. The World Economy 19: 533-43

Pöyhönen P. (1963) A Tentative Model for the Volume of Trade between Countries. Weltwirtschaftliches Archiv 90: 93-99

Rose A. (2000) One Money, one Market: Estimating the Effect of Common Currencies on Trade. Economic Policy 15: 7-46

Soloaga I., Winters L. (2001) How has Regionalism in the Nineties affected Trade? North American Journal of Economics and Finance 12: 1-29.

Summers L. (1991) Regionalism and the World Trading System. In Policy Implications of Trade and Currency Zones, Federal Reserve Bank of Kansas City, Wyoming

Tinbergen J. (1962) Shaping the World Economy: Suggestions for an International Economic Policy. New York, NY: Twentieth Century Fund

Tumbarello P. (2007) Are Regional Trade Agreements in Asia Stumbling or Building Blocks? Implications for the Mekong-3 Countries. IMF Working Paper, WP/07/53

Viner J. (1950) The Customs Union Issue. Carnegie Endowment for International Peace, New York

Wei S. (1996) Intra-National Versus International Trade: How Stubborn Are Nations in Global Integration. NBER Working Paper $n^{\circ} 5531$

World Bank (2005) Global Economic Prospects, Washington 


\section{Table 1 Variable denomination and content}

\begin{tabular}{|c|c|}
\hline$X_{i j t}$ & is the annual export flow in current dollars from country $i$ to country $j$ \\
\hline$G D P_{i t}$ and $G D P_{j t}$ & are the respective gross domestic products in dollars for countries $\mathrm{i}$ and $\mathrm{j}$ \\
\hline$D I S T_{i j}$ & $\begin{array}{l}\text { is the geodesic distance in kilometers separating the economic capitals of country } \mathrm{i} \text { and } \\
\text { country } \mathrm{j}\end{array}$ \\
\hline$R E M O T_{i j t}$ & is the average of relative distances of countries $i$ and $j$ \\
\hline$p c G D P d i f_{i j t}$ & is the absolute value of the difference of the per capita GDPs of countries $i$ and $j$ \\
\hline SIMIL $_{i j t}$ & is an indicator of the similarity in size of the GDPs of countries $i$ and $j$ \\
\hline$R E R_{i j t}$ & is the real indirect quotation of i's currency expressed in j's currency \\
\hline $\operatorname{CONTIG}_{i j}$ & $\begin{array}{l}\text { is the dummy contiguity variable with value } 1 \text { if the two partners have a common border } \\
\text { and } 0 \text { if they do not }\end{array}$ \\
\hline$L A N G_{i j}$ & $\begin{array}{l}\text { is a dummy variable that takes value } 1 \text { if the two partners share the same language and } \\
0 \text { if they do not }\end{array}$ \\
\hline RTA_intra $i_{i j t}$ & assesses intra-bloc trade regardless of the group under consideration \\
\hline$R T A_{-}^{-} X_{i j t}$ & assesses extra-bloc exports of the member countries of regional groups \\
\hline$R T A \_M_{i j t}$ & assesses extra-bloc imports of the member countries of regional groups \\
\hline$\varepsilon_{i j t}$ & is the error term \\
\hline
\end{tabular}

Note: in the equation specification (4), the $3 R T A$ variables disappear to make way for a set of the same three variables for each of the 7 agreements. 
Table 2 Intra and extra-bloc effects of trade agreements (specific effects panel)

\begin{tabular}{|c|c|c|c|}
\hline \multirow{2}{*}{ Variables } & \multicolumn{2}{|c|}{ RTA Models } & \multirow{2}{*}{$\begin{array}{c}\text { Regional groups } \\
\text { model (3) }\end{array}$} \\
\hline & (1) & $(2)$ & \\
\hline Exporter GDP $\left(\ln \left(G D P_{i t}\right)\right)$ & $0,53 * * *(31,29)$ & $0,38 * * *(16,94)$ & $0,48 * * *(26,88)$ \\
\hline Importer GDP $\left(\ln \left(G D P_{j t}\right)\right)$ & $0,95 * * *(55,59)$ & $0,80 * * *(35,42)$ & $0,97 * * *(53,94)$ \\
\hline Distance $\left(\ln \left(D I S T_{i j}\right)\right)$ & - & - & - \\
\hline Relative distance $\left(\ln \left(R E M O T_{i j t}\right)\right)$ & $1,00 * * *(3,91)$ & $0,96 * * *(3,04)$ & $1,09 * * *(4,25)$ \\
\hline Difference of the per capita GDPs $\left(\ln \left(d i f G D P p c_{i j t}\right)\right)$ & $-0,02 * *(-2,56)$ & $-0,01 *(-1,83)$ & $-0,02 * * *(-2,61)$ \\
\hline Similarity in size of the GDPs $\left(\ln \left(S I M I L_{i j t}\right)\right)$ & $-0,31 * * *(-14,92)$ & $-0,26 * * *(-12,11)$ & $-0,30 * * *(-14,19)$ \\
\hline Bilateral real exchange rate $\left(\ln \left(R E R_{i j t}\right)\right)$ & $-0,02 * * *(-3,70)$ & $-0,02 * * *(-3,71)$ & $-0,02 * * *(-3,97)$ \\
\hline Contiguity $\left(C O N T I G_{i j}\right)$ & - & - & - \\
\hline Common language $\left(L A N G_{i j}\right)$ & - & - & - \\
\hline Regional trade agreements_intra-bloc $\left(R T A \_i n t r a_{i j t}\right)$ & $0,33 * * *(11,32)$ & $0,32 * * *(10,68)$ & - \\
\hline Regional trade agreements_exports $\left(R T A \_X_{i j t}\right)$ & $0,15 * * *(11,10)$ & $0,14 * * *(10,00)$ & - \\
\hline Regional trade agreements_imports $\left(R T A \_M_{i j t}\right)$ & $0,18 * * *(13,37)$ & $0,17 * * *(12,12)$ & - \\
\hline $\begin{array}{l}\text { Andean Community_intra-bloc }\left(A C N \_i n t r a_{i j t}\right) \\
\text { Andean Community_exports }\left(A C N \_X_{i j t}\right) \\
\text { Andean Community_imports }\left(A C N \_M_{i j t}\right)\end{array}$ & & & $\begin{array}{l}0.98 * * *(10.24) \\
0.14 * * *(4.63) \\
0.24 * * *(7.97)\end{array}$ \\
\hline $\begin{array}{l}\text { Asean Free Trade Area_intra-bloc }\left(A F T A \_i n t r a_{i j t}\right) \\
\text { Asean Free Trade Area_exports }\left(A F T A \_X_{i j t}\right) \\
\text { Asean Free Trade Area_imports }\left(A F T A \_M_{i j t}\right)\end{array}$ & & & $\begin{array}{c}0.53 * * *(5.71) \\
0.66 * * *(22.48) \\
0.07 * *(2.27)\end{array}$ \\
\hline $\begin{array}{l}\text { Central American Market_intra-bloc }\left(C A C M_{-} i_{i n t r} a_{i j t}\right) \\
\text { Central American Market_exports }\left(C A C M_{-} X_{i j t}\right) \\
\text { Central American Market_imports }\left(C A C M_{-} M_{i j t}\right)\end{array}$ & & & $\begin{array}{l}0.30 * * *(4.00) \\
0.11 * * *(3.87) \\
0.11 * * *(4.05)\end{array}$ \\
\hline $\begin{array}{l}\text { European Union_intra-bloc }\left(E U_{-} i n t r a_{i j t}\right) \\
\text { European Union_exports }\left(E X_{i j t}\right) \\
\text { European Union_imports }\left(E U_{-} M_{i j t}\right)\end{array}$ & & & $\begin{array}{c}0.09 * *(2.36) \\
0.11 * * *(4.28) \\
0.04 *(1.76)\end{array}$ \\
\hline $\begin{array}{l}\text { Eurozone_intra-bloc }\left(E M U_{-} \text {intra }_{i j t}\right) \\
\text { Eurozone_exports }\left(E M X_{i j t}\right) \\
\text { Eurozone_imports }\left(E M U_{-} M_{i j t}\right)\end{array}$ & & & $\begin{array}{c}0.15 * * *(3.19) \\
0.07 * * *(2.71) \\
0.05 *(1.70)\end{array}$ \\
\hline $\begin{array}{l}\text { Mercosur_intra-bloc }\left(M E R C_{-} i n t r a_{i j t}\right) \\
\text { Mercosur_exports }\left(M E R C_{-} X_{i j t}\right) \\
\text { Mercosur_imports }\left(M E R C_{-} M_{i j t}\right)\end{array}$ & & & $\begin{array}{c}0.32 * * *(4.28) \\
0.06 * *(2.18) \\
0.28 * * *(10.67)\end{array}$ \\
\hline $\begin{array}{l}\text { North American Area_intra-bloc }\left(N A F T A \_i n t r a_{i j t}\right) \\
\text { North American Area_exports }\left(N A F T A \_X_{i j t}\right) \\
\text { North American Area_imports }\left(N A F T A \_M_{i j t}\right)\end{array}$ & & & $\begin{array}{c}0.45^{* * *}(2.73) \\
-0.13^{* * *}(-3.69) \\
0.21^{* * *}(6.00)\end{array}$ \\
\hline Intercept & $-23,15^{* * *}(-9,96)$ & $-19,32 * * *(-6,50)$ & $-23,48 * * *(-10,12)$ \\
\hline $\begin{array}{l}\text { Number of observations } \\
\text { Number of groups / number of years } \\
\text { Fischer Test (specific effects) } \\
\text { Hausman Test, chi2 (12) (fixed effects) } \\
\mathrm{R}^{2} \text { within }\end{array}$ & $\begin{array}{c}49000 \\
2450 ; 20 \\
50,12 * * * \\
1838 * * * \\
0,32\end{array}$ & $\begin{array}{c}49000 \\
2450 ; 20 \\
49,32 * * * \\
1769 * * * \\
0,32\end{array}$ & $\begin{array}{c}49000 \\
2450 ; 20 \\
43,69 * * * \\
1215 * * * \\
0,33 \\
\end{array}$ \\
\hline
\end{tabular}

$* * *, * *$ and $*$ denote that variables are statistically significant at $1 \%, 5 \%$ and $10 \%$ respectively.

(1) Model assessing the Regional Trade Agreements (RTA) together.

(2) Model (1) with 20 temporal dummy variables, not reported, all coefficients being positive and significant. 


\section{Table 3 Typology of trade creations and diversions}

\begin{tabular}{|c|c|l|}
\hline Acronym & Designation & \multicolumn{1}{c|}{ Effect of regional grouping } \\
\hline ITC & Intra-bloc trade creation & Stimulating effect on trade between partners \\
\hline XTC & Export trade creation & Stimulating effect on exports to the rest of the world \\
\hline MTC & Import trade creation & Stimulating effect on imports from the rest of the world \\
\hline XTD & Export trade diversion & Exports to the rest of world are replaced by intra-bloc trade \\
\hline MTD & Import trade diversion & Imports from the rest of world are replaced by intra-bloc trade \\
\hline
\end{tabular}

\section{Table 4 Creations / diversions and the typology of the blocs}

\begin{tabular}{|c|c|c|c|c|}
\hline \multicolumn{3}{|c|}{ Sign of regional coefficients } & \multirow[b]{2}{*}{$\begin{array}{c}\text { EFFECTS of TRADE CREATION } / \\
\text { DIVERSION* }\end{array}$} & \multirow[b]{2}{*}{$\begin{array}{c}\text { BUILDING / STUMBLING } \\
\text { BLOCK }\end{array}$} \\
\hline $\begin{array}{c}\mathrm{d}_{1} \\
\text { Intra-bloc } \\
\text { trade }\end{array}$ & $\begin{array}{c}\mathbf{d}_{\mathbf{x}} \\
\text { Extra-bloc } \\
\text { exports }\end{array}$ & $\begin{array}{c}\mathbf{d}_{\mathrm{M}} \\
\text { Extra-bloc } \\
\text { imports }\end{array}$ & & \\
\hline+ & + & + & ITC, XTC and MTC & Building block \\
\hline+ & + & - & $\begin{array}{l}\text { If } \mathrm{d}_{1}>\left|\mathrm{d}_{\mathrm{M}}\right|: \text { ITC, XTC, MTD } \\
\text { If }\left|\mathrm{d}_{\mathrm{M}}\right|>\mathrm{d}_{1}: \text { XTC, MTD }\end{array}$ & $\begin{array}{l}\text { Building block if } \mathrm{d}_{\mathrm{X}}>\left|\mathrm{d}_{\mathrm{M}}\right| \text { or } \\
\text { stumbling block if }\left|\mathrm{d}_{\mathrm{M}}\right|>\mathrm{d}_{\mathrm{X}}\end{array}$ \\
\hline+ & - & + & $\begin{array}{l}\text { If } \mathrm{d}_{1}>\left|\mathrm{d}_{\mathrm{X}}\right|: \text { ITC, XTD, MTC } \\
\text { If }\left|\mathrm{d}_{\mathrm{X}}\right|>\mathrm{d}_{1}: \text { XTD, MTC }\end{array}$ & $\begin{array}{l}\text { Building block if } \mathrm{d}_{M}>\left|\mathrm{d}_{\mathrm{X}}\right| \text { or } \\
\text { stumbling block if }\left|\mathrm{d}_{X}\right|>\mathrm{d}_{M}\end{array}$ \\
\hline+ & - & - & $\begin{array}{l}\text { If } \mathrm{d}_{1}>\left|\mathrm{d}_{\mathrm{X}}+\mathrm{d}_{\mathrm{M}}\right|: \text { ITC, XTD and MTD } \\
\text { If }\left|\mathrm{d}_{\mathrm{X}}+\mathrm{d}_{\mathrm{M}}\right|>\mathrm{d}_{1}: \text { XTD and/or MTD }\end{array}$ & Stumbling block \\
\hline
\end{tabular}

*Cf. Table 3 for the meaning of acronyms

Note: if the sign of $\mathrm{d}_{1}$ is negative, an occurrence rarely seen in the empirical literature, there cannot be a trade diversion, which implies a substitution of extra-bloc flow by an intra-bloc flow resulting from the formation of the group. 


\section{APPENDIX 1}

\section{Regional groups and member countries included in the estimate}

\begin{tabular}{|l|l|c|c|l|}
\hline \multicolumn{1}{|c|}{ Acronyms } & \multicolumn{1}{|c|}{ Designation } & $\begin{array}{c}\text { Implemen- } \\
\text { tation (1) }\end{array}$ & $\begin{array}{c}\text { Type of } \\
\text { agreement }\end{array}$ & \multicolumn{1}{|c|}{ Member countries (2) } \\
\hline ACN & $\begin{array}{l}\text { Andean Community } \\
\text { of Nations }\end{array}$ & 1992 & Customs union & Bolivia, Colombia, Ecuador, Peru, Venezuela \\
\hline AFTA & Asean Free trade area & 1993 & Free trade area & $\begin{array}{l}\text { Indonesia, Malaysia, Philippines, Singapore, } \\
\text { Thailand }\end{array}$ \\
\hline CACM & $\begin{array}{l}\text { Central American } \\
\text { Common Market }\end{array}$ & 1993 & Customs union & $\begin{array}{l}\text { Costa Rica, El Salvador, Guatemala, } \\
\text { Honduras, Nicaragua, Panama }\end{array}$ \\
\hline EU & European Union & 1987 & Single market & $\begin{array}{l}\text { Belgium, Denmark, France, Germany, } \\
\text { Greece, Ireland, Italy, Luxembourg, } \\
\text { Netherlands, Portugal, Spain, United } \\
\text { Kingdom, Austria (1995), Finland (1995), } \\
\text { Sweden (1995), Hungary (2004), Poland } \\
\text { (2004) }\end{array}$ \\
\hline EMU & $\begin{array}{l}\text { Economic and } \\
\text { Monetary Union }\end{array}$ & 1999 & $\begin{array}{l}\text { Monetary } \\
\text { union }\end{array}$ & $\begin{array}{l}\text { Austria, Belgium, Finland, France, Germany, } \\
\text { Italy, Ireland, Luxembourg, Netherlands, } \\
\text { Portugal, Spain, Greece (2001) }\end{array}$ \\
\hline MERCOSUR & $\begin{array}{l}\text { Southern Common } \\
\text { Market }\end{array}$ & 1991 & Customs union & $\begin{array}{l}\text { Argentina, Brazil, Paraguay, Uruguay, Chile } \\
\text { (1996), Bolivia (1997) }\end{array}$ \\
\hline NAFTA & $\begin{array}{l}\text { North American Free } \\
\text { Trade Association }\end{array}$ & 1994 & Free trade area & Canada, Mexico, United States \\
\hline
\end{tabular}

(1) Year of the agreement's coming into force (AFTA, EMU, NAFTA, MERCOSUR), or year of relaunching or consolidation of the group (CAN, CACM, EU).

(2) Due to a lack of exhaustive data for the whole period under study (1986-2005), Burma, Brunei, Cambodia and Laos (AFTA members) are not included in the estimate. The same is true for new members joining the European Union in 2004, with the exception of Hungary and Poland. In the case of an enlargement, the entrance year appears into brackets.

\section{APPENDIX 2}

\section{Data sources}

\begin{tabular}{|c|c|}
\hline DATA & SOURCES \\
\hline Bilateral export flows & $\begin{array}{l}\text { United Nations - COMTRADE database SITC2 (Standard } \\
\text { International Trade Classification Revision 2) }\end{array}$ \\
\hline $\begin{array}{l}\text { GDP in current dollars } \\
\text { Per capita GDP in current dollars } \\
\text { CPI (Consumer price index), annual average }\end{array}$ & IMF World Economic Outlook, April 2007 \\
\hline NER (Nominal exchange rate), annual average & IMF, International Financial Statistic \\
\hline Distance, contiguity, common language & $\begin{array}{l}\text { "Distances" database, CEPII (Centre d'Etudes Prospectives } \\
\text { et d'Informations Internationales), Paris }\end{array}$ \\
\hline
\end{tabular}

